\title{
Electronic Voting and Credible Election in Nigeria: A Study of Owerri Senatorial Zone
}

\author{
Nnaeto Japhet Olusadum ${ }^{1} \&$ Ndoh Juliet Anulika ${ }^{2}$ \\ ${ }^{1}$ Gregory University, Uturu, Nigeria \\ ${ }^{2}$ Imo State University, Owerri, Nigeria \\ Correspondence: Nnaeto Japhet Olusadum, Gregory University, Uturu, Nigeria.
}

Received: June 16, 2018

Accepted: July 5, 2018

Online Published: July 16, 2018

doi:10.5430/jms.v9n3p30

URL: https://doi.org/10.5430/jms.v9n3p30

\begin{abstract}
The study is basically to examine electronic-voting in Nigeria elections as an improvement on the traditional paper voting with a focus on Owerri Senatorial Zone, Imo State. Worried by the frequent and debilitating incidences of electoral fraud and disenfranchisement of voters for unsubstantiated reasons, the study tended to sample opinion of respondents in Owerri on the subject as a way of strengthening democracy. Martin Hagen theory of e-democracy was adopted as theoretical framework. Hagen construes e-democracy as a strategic tool to strengthen democratic practices using the information and computer technology (ICT). The study is a survey attempt which made use of structured questionnaire to elicit information from respondents. Simple per centage was used for data analysis. It is our finding among others that e-voting will reduce incidences of election fraud especially in the areas of voting and counting of votes, and also the physically challenged qualified voters and citizens living and working abroad will have opportunity to cast their votes. The study concludes that Nigeria must cash in on flourishing (ICT) to fight endemic electoral irregularities in Nigeria through firm belief in and avowed adoption of e-voting. The study recommended among others institutionalization of legal frameworks and structures that will formidably support the practice of e-voting in Owerri senatorial zone in particular and Nigeria in general.
\end{abstract}

Keywords: e-democracy, e-voting, senatorial zone, INEC, electoral

\section{Introduction}

Information technology has become a tool for politics, thus making electronic republic possible. It is all about e-government which simply means according to United Nations Global E-Government Readiness Report 2004 as cited in Akpan-Obong \& Alozie (2016,p.15) a "programmatic" tool through which socioeconomic and environmental services are rendered to the population while also fostering as on participation and social inclusion. Operation of public administration has been digitalized to the extent that so many things can be achieved precisely, correctly and within a short while. Democratic politics, especially the area of election is a strong determinant of political development of a state. It is in the quest to achieve democratic government and good governance that e-voting is introduced as a credible alternative to the traditional paper voting system. The aim of e-voting is to afford the citizens of the country the opportunity to participate in the voting process from where ever they are. E-voting is an electronic means of handling electoral matters which include voting, transmission and counting of ballots. It refers to voting using electronic means to either aid or take care of the chores of casting and counting votes. It can also involve transmission of ballots and votes via telephone, private computer network, or the internet (https://en.m.wikipedia.org/wiki/Electronic_voting. E -voting is one of the most important aspects of e-democracy as its introduction can accommodate the political and democratic interests of citizens who are either physically challenged or are outside the shores of Nigeria.

\subsection{Statement of the Problem}

The great need for transparency, equal opportunity and rule of law as major tenets of democratic institutions cannot be over-emphasized. The exercise of franchise is the fulcrum on which democracy revolves. Unfortunately anti-democratic practices such as falsification of voters' register, under-age voting, snatching of ballot boxes, denial of voting rights to qualified physically challenged and those who live and work abroad, and deliberate falsification of vote figures to favour a particular candidate have tremendously and irredeemably bastardized the democratic 
procedure. This scenario has simply places a question on the Nigeria democracy. Worst still, political office holders that assumed leadership positions through such flawed and faulted procedure operate like hirelings, not caring about the need to work for the interest of the electorates but will concentrate on self-enrichment and that of their godfathers and cronies. The end results of this situation are further impoverishment and subjugation of already poverty-stricken citizens and further depletion of already ailing economy. More often than not, the traditional paper type of voting has given rise to many intractable electoral irregularities which have marred the possibility of recording free, fair and credible election in Nigeria. These challenges and irregularities have scuttled the real essence of democratic governance. However, democratic politics can be at its meaningful best if measures that can ensure transparency and equal opportunity to vote and be voted for, including making provision for qualified voters irrespective of physical challenges and place of residence. Introduction of electronic voting can take care of these challenges.

\subsection{Objective of the Study}

The study is set out to achieve the following three primary objectives.

(1). To ascertain whether the voters in Owerri Senatorial Zone of Imo State understand the dynamics of e-voting.

(2). to investigate whether introduction of e-voting can ensure credible voting process in Nigeria.

(3). to ascertain advantages of e-voting over traditional paper voting system.

\subsection{Research Questions}

The following research questions will guide the study;

(1). Do voters in Owerri Senatorial Zone understand the dynamics of e-voting?

(2). Will adoption of e-voting ensure credible elections in Nigeria?

(3).What informs the preference of e-voting over traditional paper voting system?

\subsection{Significance of the Study}

The concept of electronic-voting is relatively new in practice among world major democracies. It is an offshoot of the Information and Computer Technology (ICT) revolution that heralded the beginning of the twenty first $\left(21^{\text {st }}\right)$ centuries. The justification for this study lies in its ascertained and proven benefit to voters with disability and those that live and work abroad in particular and democracy in general through the introduction of relative transparency in democratic politics. The study will also sensitize the Nigerian electoral umpire, the Independent National Electoral Commission (INEC) on the urgent need to consider improving the conduct of elections in Nigeria through the adoption of electronic voting. Nigeria and indeed many democracies do have difficulties in collation and counting of votes cast. It is at this stage of election that worst and unsettling electoral frauds are committed. Adoption of e-voting will definitely reduce the degree of frauds at this level of election exercise. Besides, the study will be a springboard for Nigerians to begin to ask for true and equal representation and participation for every qualified voter irrespective of physical condition and location as at the time of election. Furthermore, since e-democracy or e-voting is a recent jargon in the literature of political science, the study will make academic input to the body of literature as well as serve as applied research which will facilitate strategic policy action for development.

\section{Understanding the Concept of Electronic Voting (E-Voting)}

The acronym e-voting means electronic voting which ordinarily means voting with the aid of electronic devices such as computer network, internet, telephone etc. E-voting has to do with transmission of ballots and votes with the help of telephone, private computer networks or internet (https://en.m.wikipedia.org/wiki/Electronic_voting).It is one of the modern ways of ensuring credibility of election process in democratic countries. E-voting has given the citizens of affected countries who are serving abroad or who are in remote locations the opportunity to be part of the important decision of electing their leaders at various levels.

E-voting is a term of broader meaning, and internet voting is just one of its forms. Electronic voting, however, refers to technologies that are used within voting process such as: digital broadcasting, telephony, the internet (Magdalena, 2014, p.105).E-voting has been successful in the United States of America and European countries like Austria, Belgium, United Kingdom, Italy Switzerland etc. The application of information and communication technology (ICT) in voting has a potential to overcome barriers which hinder or limit the electorates from participating in decision making process Magdalena, 2010.p.77). E-voting is gaining wider currency and thus has assumed the most important aspect of e-democracy in an increasing number of countries. According to Magdalena, e-voting is a term encompassing several different types of voting, embracing both electronic means of casting a vote and electronic means of counting votes. The e-voting technology can include punch cards, optical scan voting systems and 
specialized voting kiosks. It is very important at this juncture to make this appropriate clarification about e-voting (electronic voting) and I-voting (internet voting). Though the two concepts are closely related, there is a tiny but important distinction between the two. While electronic voting comprises other electronic voting technologies and techniques, internet voting strictly means remote voting with a computer that is connected to the internet. Therefore, electronic voting is broader in scope and more encompassing than internet voting which strictly expresses voting via internet devices

\subsection{Electronic Voting and Its Forms}

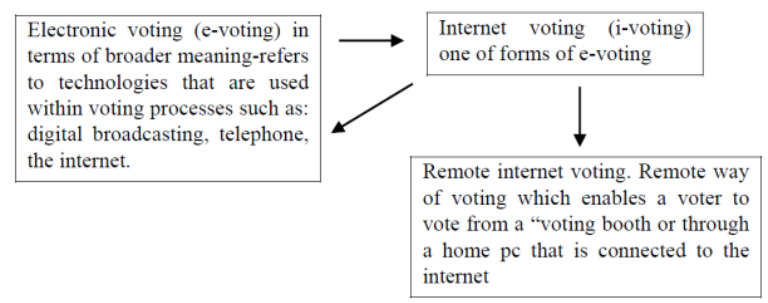

Figure 1

Source: Magdalena-Karg, 2010

Technologically, there are about six main e-voting stages. The e-voting stages start with voters' registration. At this stage, voters are defined and given authentication data to log into the system. Next stage is the actual authentication of voters which means verifying whether they are qualified to exercise franchise. Third stage is the voting and voters' saving stage. This is where the eligible voters cast votes and e-voting system saves the received votes from voters. Next is the vote managing stage. At this stage, votes are first managed, sorted and prepared for counting. The fifth stage involves counting the votes that is to decrypt or decode and count the votes and release the final tally. The last (sixth) stage of e-voting is to carry out the auditing which involves checking to make sure that eligible voters voted and that their votes are properly computed , and that they count in deciding who wins or loses.(Magdalena, 2010).

\subsection{The Good Side of Electronic Voting}

The study is specifically meant to create empirical awareness on the existence and practice of electronic voting with a view to drawing the attention of Nigeria to the need for its adoption in 2019 general elections and subsequent exercises in Nigeria. In trying to achieve this objective, it is apposite to discuss the advantages and challenges of e-voting as experienced by countries that have or are still practicing it. We shall juxtapose this information with data from respondents in order to make empirical decision on whether electronic voting can enhance democracy in Nigeria or not. Advantages of e-voting are numerous likewise the challenges. Mourine and Ephias (2013) identified a few advantages of e-voting, though noting that its adoption by various countries is dependent on certain conditions among which are its advantages over the challenges.

Accordingly, one of the benefits is that e-voting may help make voting more cost effective and more convenient for voters and may even increase voter turnout (Svensson and Leene,2003). In some countries, citizens show great apathy during elections because of fear of election violence. Adoption of e-voting will encourage such voters to exercise their franchise through internet voting right from the comfort of their homes. Secondly e-voting can play important role in enhancing the voting process through increasing the low turnout among the youths who may not be satisfied with the traditional paper-based process of voting (Xenakias and Macintosh, 2005). We have noted that e-voting serves different advantages to different countries. According to Xenakias and Macintosh, e-voting may successfully convince the youths to participate in voting process because of its preference to traditional paper-based election. Specifically, e-voting can help increase and improve the participation of disabled voters who ordinarily may not be able to participate in the traditional voting arrangement (Baker and Moon, 2005). Furthermore, Mourine and Ephias (2010) opine that the Philippine adopted an electronic counting solution and it helped them to deal with issues related to fraud during counting process. However, for the fact that it works for the Philippines does not mean it will be successful to other democracies in similar proportion. While noting the gains of e-voting Magdalena (2014) emphasizes that the intention of e-voting is not to replace the traditional way of voting but to use ICT to provide alternatives aimed at increasing accessibility to voting process for wider variety of citizens, inclusive of disabled and those working either abroad or in remote areas. Besides, electoral authorities use computer systems to make their 
internal management and communications more effective, to systematize voter registration records and to communicate with voters among other tasks (Blanc, 2007.p.11).This will help to record appreciable precision in election administration. Finally, e-voting may in the long run reduce expenses associated with staffing poll sites (Parliament, 2010) It can also reduce incidence of personal clashes at polling stations. It is commonplace, especially in developing democracies that representatives of political parties or party agents may engage in scuffles over disagreement in the handling of electoral matters at the polling stations. With the adoption of e-voting, such scenarios will rarely manifest as virtually every process will be done electronically.

\subsection{Challenges Associated With Electronic Voting}

Every phenomenon has its pros and cons .As good as electronic voting may be, it has obvious limitations. However, overcoming its challenges is dependent upon the readiness of adopting countries to control the challenges inherent or associated with e-voting. Electronic voting is machine based; internet enabled and is susceptible to internet or virus attacks. There is expressed concern that electronic voting can lead to massive electoral fraud. It is possible the software that can generate passwords for express permission into the site may be accessed and alterations that may change the outcome of the voting exercise may occur, thus raising scenarios that will definitely question the credibility of the electoral exercise. Electronic voting raises transparency related issues as all processes of data generation, transformation, and storage occur in "black boxes" that are often not fully transparent even for technical experts (Gerlach.U.Gasser, 2009.p.5). Furthermore, the concern about voters' authentication has been expressed. This is in view of the fact there is no universally available form of digital identification and as such cannot ensure internet voters are really the people expected to vote or voters who are really who they claim to be. On a general note, many countries consider it a big risk to adopt electronic voting on the account of obvious difficulty associated with security and maintenance of the system. One of the essences of considering e-voting is security of votes and achievement of credible election. If this ambition is jeopardized by any factor, e-voting efficacy will lose currency. However, the challenges associated with e-voting can be overcome with transparent dedication from the implementers. On a general analysis, a sincere implementation of e-voting will always be better or hugely complementary to the traditional paper type of voting in the $21^{\text {st }}$ century.

\subsection{Use of Electronic Voting in Europe}

As we try through this study to draw Nigeria into electronic voting awareness, it is apt to also draw her attention to some countries of Europe which had and are still having such experience at different times and levels. It is however possible that the level of success recorded by one country may not be same with another. It will surely vary. Our reason for this exposition is for Nigeria to be abreast with countries that have had such experience in case it considers it for adoption.

Table1. E=Voting in European countries

\begin{tabular}{lll}
\hline Countries & Application Of E-Voting & Time \\
\hline Austria & Test Election for Austrians Living Abroad & $12-14.10 .2006$ \\
\hline Belgium & Voting machines -Tests & No date \\
\hline Bulgaria & Town council E-voting of Kazanluk & 07.05 .2008 \\
\hline Estonia & Municipal elections & $10-12.10 .2005$ \\
\hline Estonia & Parliamentary elections & $26-28.02 .2007$ \\
\hline Finland & E-voting in local elections in Karkkila, Kaunianien, Vihti & 10.2008 \\
\hline Italy & Administration elections- Autonomous Province of Trento & 08.05 .2005 \\
\hline The Netherlands & Parliamentary elections-Lower House & $18-22.11 .2006$ \\
\hline Portugal & Parliamentary general elections-Voters abroad & 20.02 .2005 \\
\hline Portugal & Elections for the European Parliament & 06.2004 \\
\hline Spain & Referedum, Constitution for Europe-53 municipalities & $01-18.02 .2005$ \\
\hline Great Britain & Local Government (Liverpool, Sheffield) & $2003,2005,2007$ \\
\hline Switzerland & Neuenburg, Zurich, Geneva (February 2009 constitution) & From 2001 test voting \\
\hline
\end{tabular}

Source: Magdelena-Karg, 2014 
It is worthy of note that Switzerland and Estonia record best successful attempts in electronic voting in Europe. E-voting was initiated in Switzerland in the year 2000.The core reason for implementing e-voting in Switzerland was to make voting in referenda and elections especially for disabled and citizens living abroad very possible and easy. To increase voters' turnout was also a prime reason. Estonia becomes another European country that recorded astounding success in electronic voting. Many studies have reported that attitude of Estonians towards electronic voting has been and still is positive. This high confidence and success level may precipitate the institutionalization of e-voting in Estonia.

\subsection{Efforts for a More Effective E-Voting}

For a more effective e-voting, the National Science Foundation (NSF) Internet Voting Report in 2001 grouped internet voting system into three. Such grouping include poll site voting which presents the voters with great convenience and as well makes the tallying process less cumbersome and fast. Another category is kiosk voting which has to with the location of voting machine in convenient location that are far away from the traditional polling places. Such locations may include malls, libraries, schools etc which must be under security checks to prevent any form of unauthorized access. Finally there is the remote internet voting. This category simply stresses on making voting possible for voters from any location. However, there is fear that the existing technology may not be adequate to check the risk involved. Furthermore, the California Internet Voting Report in 2000 took an evolutionary strategy in suggesting improvement on e-voting. It emphasized on the need for guiding policies that must ensure a total protection of the e-voting system. On December 12, 1995, Philip Klein in a seminar on Cryptology unveiled an "Untraceable, Universally Verifiable Voting Scheme" presenting a remote voters scheme which can apply the technique of blinded signature to a voter's ballot so that it is impossible for anyone to trace the ballot back to the voter. This scheme will achieve privacy, convenience, and universal verifiability. In 2002, Rubin has stressed on the new risks faced by e-voting because of the introduction of state-of-the-art technology into election process. The voting platform faces the major risks such as malicious payload like attack programmes, and delivery mechanism like worms, viruses and bugs etc. Caution has been expressed against these risks to e-voting. A United Kingdom base e-democracy consultant in the UK Cabinet Office revealed "threats, potential sources of attacks and possible methods of attack in such voting system. It also provided the practitioners of e-voting with the security objectives and what is required to run such system without being easily being susceptible to attacks. The National Computer Security Conference titled "Security Criteria for Voting", organized by Peter G. Neumann in 1993, concluded that criteria for confidentiality, integrity, availability, reliability, and assurance for computer system involved in e-voting failed assessment of realizability meaning that e-voting may not assure the operational achievement of these criteria. Lance J. Hoffman Technical Report on "Internet voting: will it spur or corrupt Democracy" maintained that besides technical threats to e-voting, the socio-political issues remain credible threats to the success of the system and thus must be checked.

\subsection{Background of Study Area}

The area of study is Owerri Senatorial Zone. Imo State is made of three senatorial zones, and in order of size and population, Owerri senatorial zone ranks second. The senatorial zone comprises nine local government areas including the municipality. Its local government areas include; Aboh Mbaise, Ahiara Mbaise, Ezinihite Mbaise, Ikeduru, Mbaitoli, Ngor Okpala, Owerri Municipal, Owerri West and Owerri North. The zone commands concentration of elites and business experts. This explains the choice of the area for the study. In Owerri zone, there is huge presence of public/civil servants who are not totally uninformed of topic of study. There are about five tertiary institutions comprising universities, polytechnics and colleges of education, making it a zone with a large number of educated persons. In view of the need for considerable level of literacy for participating in e-voting, Owerri senatorial zone with its numerous educated citizens serves a good pilot place for e-voting aspect of e-democracy.

\subsection{Theoretical Consideration}

The theoretical consideration will be based on the concept of electronic democracy as espoused by Martin Hagen (2000). Hagen construes e-democracy as a strategic tool to strengthen democratic practices using the information and computer technology (ICT). He thinks certain people are usually omitted in the process of making important political decisions of their countries by way of unintended but unsatisfactorily explained disenfranchisement. For Martin, e-democracy is a form of development and reinforcement of democracy which uses new communication technology to strengthen political power of those often omitted in important political processes. The theory of e-democracy has been adopted in many democratic political systems across the world especially in Europe with uncommon success. It 
can serve affirmative action purpose for the large number of citizens negatively affected by the paper-based voting system.

\section{Methodology}

The population of study consists of nine local government areas that made up Owerri senatorial zone, Imo State. Two hundred respondents representing the sample size was judgmentally, and on the basis of convenience selected, seeing that it is impossible to study the entire population of the senatorial zone. The selected respondents adequately possess the information needed for the study. Imo State and particularly Owerri senatorial zone was selected for the study because it host a well educated, informed and relatively information and computer technology complaints which is one of the pre-requisites for electronic voting. Structured questionnaire was designed using Likert response scale of (1) strongly agree-SA, (2) agree-A, (3).strongly disagree-SD, (4).Undecided-U, and (5). Disagree-D, Mensah et al (2017, p.54). Simple per cent age shall be used to analyze the data collected from respondents to determine the level of acceptability or desirability of respondents for adoption of electronic voting in 2019 and subsequent general elections in Nigeria.

\section{Data Presentation and Analysis}

Table 2. Presentation of primary data and analysis

\begin{tabular}{llll}
\hline Distribution of Location & Number Distributed & Number Returned & Number of Percentage \\
\hline Public servant & 50 & 50 & 50 \\
\hline Academic & 50 & 50 & 50 \\
\hline Politicians & 50 & 50 & 50 \\
\hline Self-employed & 50 & 50 & 50 \\
\hline Total & 200 & 200 & 100 \\
\hline
\end{tabular}

Source: survey by Researcher, 2018

The table above shows the equal distribution of two hundred (200) copies of questionnaire among different cadre of the respondents that form our sample size. Surprisingly, the 200 copies of questionnaire distributed were returned. This could be attributed to the long yearning by Nigerian electorates for participation in a study seeking to introduce e-voting into the Nigerian political system and, the interesting nature of the topic to the respondents. Secondly, the astute approach adopted by our research assistants while distributing the copies of the questionnaire also played important role to achieving this feat.

Table 3. Question 1: Electronic Voting is needed in Nigeria during 2019 general election and beyond

\begin{tabular}{lll}
\hline OPTIONS & RESPONSE & PERCENTAGE \\
\hline SA & 80 & 40 \\
\hline A & 70 & 35 \\
\hline U & -- & -- \\
\hline SD & 20 & 10 \\
\hline D & 30 & 15 \\
\hline Total & 200 & 100 \\
\hline
\end{tabular}

Source: survey data, 2018

The data above shows clearly respondents' preference of e-voting to traditional paper system of voting. 80 of the respondents representing $40 \%$ strongly agreed that it is high time Nigeria introduced e-voting brand of e-democracy. This is supported by $35 \%$ of the sample size that agreed to introduction of e-voting as against tiny negative $10 \%$ and $15 \%$ of respondents against the e-voting, respectively. This record proved a higher demand for e-voting in Nigeria by voters in Owerri Senatorial Zone. 
Table 4. Question 2: E-voting can strengthen democracy in Nigeria by extending participation to the disabled and citizens abroad

\begin{tabular}{lll}
\hline Options & Response & Percent \\
\hline SA & 75 & 37.5 \\
\hline A & 65 & 32.5 \\
\hline U & 10 & 5 \\
\hline SD & 20 & 10 \\
\hline D & 30 & 15 \\
\hline TOTAL & 200 & 100 \\
\hline
\end{tabular}

Source: survey data, 2018

The data presented indicates that e-voting can strengthen our nascent democracy by extending opportunity for participation to both disabled citizens and those living abroad. $37.5 \%$ and $32.5 \%$ of respondents respectively think the above statement is correct about e-voting in Owerri senatorial zone and Nigeria. While 5\% is undecided, $10 \%$ and $15 \%$ of respondents strongly disagree and disagree respectively that e-voting will strengthen democratic practices in Nigeria. However, the per cent response of SA $(37.5 \%)$ and A (32.5\%) empirically indicated that e-voting is capable of strengthening our democracy by enfranchising disabled citizens and those working and living abroad.

Table 5. Question 3: poor power situation in Nigeria will negatively affect successful implementation of ICT based e-voting in Nigeria

\begin{tabular}{lll}
\hline OPTION & RESPONSE & PERNCENT \\
\hline SA & 90 & 45 \\
\hline A & 80 & 40 \\
\hline U & - & - \\
\hline SD & - & - \\
\hline D & 30 & 15 \\
\hline TOTAL & 200 & 100 \\
\hline
\end{tabular}

Source: survey, 2018

Despite the wide acceptance of e-voting by respondents in Owerri senatorial zone, there is palpable fear among them that the first real challenge to the system is poor power situation in Nigeria. A high $45 \%$ and $40 \%$ of the respondents express fear that the ICT based concept may well be marred by poor power issues in Nigeria while an infinitesimal $15 \%$ doubts the popular proposition. This response clearly identified first major challenge to e-voting concept and simply points to the need to fix the power sector before real success could be made in the e-voting proposition.

Table 6. Question 4: Voters in Owerri senatorial zone are ICT compliant enough to engage e-voting

\begin{tabular}{lll}
\hline Options & Response & Percent \\
\hline SA & 70 & 35 \\
\hline A & 60 & 30 \\
\hline U & 10 & 5 \\
\hline SD & 20 & 10 \\
\hline D & 40 & 20 \\
\hline TOTAL & 200 & 100 \\
\hline
\end{tabular}

Source: Survey Data, 2018 
Respondents in Owerri senatorial zone think they have ICT knowledge required to participate in e-voting in Nigeria. The percent response of options SA $(35 \%)$ and A $(30 \%)$ respectively attest to respondents' ICT readiness for e-voting. Besides, the metropolitan status of Owerri may have facilitated ICT compliance among residents of Owerri. While $5 \%$ is undecided, $10 \%$ and $20 \%$ respectively strongly disagree and disagree on the question. Therefore, Owerri Senatorial Zone is ICT compliant enough to be a pilot location to test e-voting in Nigeria.

Table 7. Question 5: E-voting will minimize electoral fraud in Owerri senatorial zone

Source: Survey data, 2018

\begin{tabular}{lll}
\hline Options & Response & Percent \\
\hline SA & 90 & 45 \\
\hline A & 80 & 40 \\
\hline U & - & - \\
\hline SD & - & - \\
\hline D & 30 & 15 \\
\hline TOTAL & 200 & 100 \\
\hline DOT
\end{tabular}

Exasperated by the spate of electoral malpractices in Owerri senatorial zone in particular and Nigeria in general, 45\% and $40 \%$ of respondents "strongly agreed and agreed" respectively that adoption of e-voting will definitely cut down the rate of election fraud in Nigeria body-politick. This is due to the fact that most of the electoral processes will be powered electronically leaving little hole for fraudulent manipulations. However, while no response to U and SD, $15 \%$ of respondents disagreed that voting in Owerri senatorial zone and indeed in Nigeria will get better with the introduction of e-voting system. With high positive response of $45 \%$ by SA and $40 \%$ of A, it therefore means that introduction of e-voting will reduce electoral frauds in Owerri senatorial zone in particular and Nigeria in general.

Table 8. Question 6: Voters in the zone prefer e-voting to traditional paper-based voting system

Source: Survey data, 2018

\begin{tabular}{lll}
\hline Options & Response & Per cent \\
\hline SA & 70 & 35 \\
\hline A & 60 & 30 \\
\hline U & 10 & 5 \\
\hline SD & 20 & 10 \\
\hline D & 40 & 20 \\
\hline TOTAL & 200 & 100 \\
\hline
\end{tabular}

The per cent "SA and A" responses of $35 \%$ and $30 \%$ of voters respectively in Owerri senatorial zone indicates that the zone craves for adoption of e-voting over the traditional paper-voting. Such gains as easy counting of votes, precision-guided election and wider citizens' participation may have informed respondents' preference of e-voting to paper-based one. While $10 \%$ and $20 \%$ strongly disagree and disagree respectively, $5 \%$ remains undecided. Therefore, the high per cent response of voters SA $(35 \%)$ and A $(30 \%)$ respectively indicate voters' preference of e-voting to traditional paper voting

Table 9. Question 7: Advantages of e-voting far outweigh the inherent challenges

Source: survey data, 2018

\begin{tabular}{lll}
\hline Options & Response & Per cent \\
\hline SA & 80 & 40 \\
\hline A & 60 & 30 \\
\hline U & - & - \\
\hline SD & 20 & 10 \\
\hline D & 40 & 20 \\
\hline TOTAL & 200 & 100 \\
\hline
\end{tabular}


A look at the data presented attest to the judgment of respondents in Owerri senatorial zone that e-voting has better advantage than challenges, thus recommends the zone and Nigeria to go for it. Statistically, $40 \%$ and $30 \%$ of respondents respectively "agreed strongly and agreed" that the risk of adopting e-voting is far more eclipsed by the good side. However, while $10 \%$ strongly disagreed, $20 \%$ disagreed. The respondents therefore believe that though e-voting has its challenges, the advantages far outweigh them.

Table 10. Question 8: Nigerian electoral body (INEC) will adopt e-voting in Nigeria

\begin{tabular}{lll}
\hline Options & Response & Percent \\
\hline SA & 70 & 35 \\
\hline A & 60 & 30 \\
\hline U & 10 & 5 \\
\hline SD & 20 & 10 \\
\hline D & 40 & 20 \\
\hline TOTAL & 200 & 100
\end{tabular}

Source: Survey data, 2018

There is very sharp belief among greater number of respondents in Owerri senatorial zone that the electoral umpire (INEC) will soon adopt e-voting in subsequent elections in Nigeria. 35\% and 30\% of respondents respectively think that INEC will soon adopt e-voting as model for elections in Nigeria. This may not be unconnected with respondents' position that advantages of e-voting outweigh its challenges. $10 \%$ and $20 \%$ of respondents have a contrary thought while $5 \%$ remains undecided. Given this response rate, it means voters in Owerri senatorial zone are optimistic INEC will adopt e-voting in future elections in Nigeria.

\section{Research Findings}

Based on the data presentation and analysis, the study makes the following findings;

(1). Voters in Owerri Senatorial Zone demand introduction of e-voting in the zone and for entire Nigeria in future elections.

(2). Voters believe that introduction of e-voting will bring credibility to Nigeria's electoral exercises.

(3). Voters agree there are enormous challenges and hurdles that Nigeria must surmount before reaping the gains of e-voting such as the persistent power and internet fluctuations in Nigeria.

(4). Voters in the zone are positive about the success of e-voting in Nigeria but they expressed concern over the prevalent hacking of systems by internet frauds.

(5). Voters agree that e-voting will ensure wider participation of citizens in decision making in Nigeria. However, it is a concern that illiterate rate, especially in the rural areas may reduce to a large extent the expected success of the exercise.

\section{Conclusion}

E-voting is strongly recommended to be introduced in Nigerian politics because of obvious advantages the study revealed it has over traditional paper type of voting. The prevalence of information and computer technology (ICT) positively affects almost every sphere of many countries' life including politics. Primary aim of the study is to introduce e-voting into Nigeria's electoral system as a credible alternative for traditional paper-based voting. This enhancement has generated certain curiosity that was hitherto not in existence among the citizens. Among the numerous benefits of information and communication technology is electronic democracy (e-democracy) which gave vent for electronic voting (e-voting). Proper implemented of e-voting is capable of reducing electoral irregularities in Nigerian body politic such as manipulation of voters registration and record, manipulation during collation and counting, disenfranchisement of physically challenged voters and voters living and working abroad etc which have proved intractable menace to the credibility of elections in Nigeria for decades. In view of the success of e-voting in European countries like Estonia, Finland and Switzerland, and in other countries like United States of America and The Philippines coupled with the strong positive responses of voters in preference for e-voting, it is believed that the prospect of e-voting in Nigeria is very positive. The importance of e-voting in terms of ensuring wider participation 
of citizens, security and credibility of election cannot be over-emphasized. For example, in Philippine it helps to deal with election fraud in the area of counting. In Estonia it ensured wider participation and voting convenience. E-voting can pose serious challenges but proper preparation can reduce the challenges to the manageable minimum.

\section{Recommendations}

1. Based on findings made from the field data and extraction from the experience of practitioner countries, Nigeria should as a matter of necessity fix power and internet related problems before nursing the thought of adopting e-voting aspect of e-democracy. This is a sine qua non for e-voting.

2. Besides, the Independent National Electoral Commission (INEC) must develop strong anti-virus and anti-hacking software to ward off credible threats capable of throwing the country into serious confusion. This is a protective strategy.

3. Furthermore, INEC must prior to any serious action in the direction of e-voting exercises, carry out sustained ward to ward enlightenment campaign of voters on the approaches to effective participation in e-voting in Nigeria. INEC may achieve it in collaboration with National Orientation Agency (NOA) and its officials resident in the localities.

4. Nigeria must contact for information, countries that adopted the system and dumped it after a few years, and also countries that adopted and are still practicing it till date. The essence of this is to know why some countries adopted and left is after some time and why some adopted and are still practicing it till date. The approach will help Nigeria make comparisons that will lead to rational decision on the e-voting policy. Germany, Netherlands; Estonia, Switzerland, Philippine and United States of America respectively are countries Nigeria may consult for credible information on e-voting.

5. INEC must ensure that the integrity of its technical contingent that mans the e-voting process is not in doubt. It must comprise people whose hearts and minds are "castrated" against partisan politics. An act of Parliament must explain to them the enormity of penalty for compromising such special assignment.

\section{References}

Akpan-Obong. P. I., \& Alozie. N. O. (2016). Information Technologies in the Nigerian Public Sector: E-governance Practice in Federal Government Institutions in Abuja.

Barker Paul, M. A., \& Moon, N. W. (2005, Novemebr). Getting out the vote: Assessing Technological, Social and Process Barriers to e-voting for people with Disabilities. The twenty-seventh Annual APPAM Research Conference, Washington.

California Internet Voting Task Force. (2000, January). A Report on the Feasibility of Internet Voting.

Gerlach, U., \& Gasser, J. (2009). Three case studies from Switzerland: E-voting. Berkman Center Research., p.5.

Hagen, M. (2000). E-democracy is a strategic tool to strengthen democratic practices using the information and computer technology (ICT).

Hoffman, L. J. (n.d). Internet Voting: Will it spur or corrupt democracy? Technical Report, Computer Science Department, The George Washington University, Washington, D. C. Retrieved from http://www.e-poll-project.net/

Josephine, P., Luther, N., \& Albert, A. (2017). Effects of compensation in Basic School Teachers' Job Satisfaction in the Northern Zone: The case of Ghana. Global Journal of Mnangement and Business Research, 17(3).

Magdalena, M. K. (2010). E-voting as a new form of civic participation in democratic procedures. Polish Political Science.

Magdalena, M. K. (2014). The use of e-voting as a new tool of e-participation in modern democracies. Poznam.

Mourine, A., \& Ephias, R. (2013, November). The adoption and challenges of electronic voting technologies within the South African Context. International Journal of Managing Information Technology (IJMIT), 5(4).

National Science Foundation. (2001). Report of the National Workshop on Internet voting: Issues and Research Agendas. Internet Policy Institute, sponsored by the National Science Foundation, conducted in cooperation with the University of Maryland and Freedom Forum.

Neumann, P. G. (1993, September). Security Criteria for Electronic Voting.16 ${ }^{\text {th }}$ National Computer Security Conference, Baltimore, Maryland. 
Okechukwu, I. (2014). Owerri Zone: Finally as Chris Asoluka goes to the poll. Retrieved from https:/www.google.com.ng/amps/s/www.thenigerianvoive.com/amp.news/163473/owerri-zone-finally-as-asolu ka-goes-to-poll.html

Parliamentary Office of Science and Technology (voting online). Postnote No.155/2010, p. 3. Retrieved November 2, 2010, from http:/www.parliamentary.uk/post/pn155.pdf

Philip, K. (1995, December). An Untraceable, Universally Verified Voting Scheme. Seminar in cryptology.

Rubin, A. D. (2002).Security consideration for remote electronic voting. Communication of the ACM, 45(12). https://doi.org/10.1145/585597.585599

Svensson, J., \& Leenes, R. (2003). E-voting in Europe: Divergent democratic practice. Information Polity, 8(1), 3-15.

UK Cabinet Office. (n.d). E-voting security study. E- Democracy Consultant, U. K. Cabinet Office. Retrieved from http://www.edemocracy.gov.uk/library/papers/study.pdf

Xenakis, J., \& Macintosh, A. (2005). E- Voting Administration: Organizational lessons learned from the development of e-voting in the U. K. ACM International Conference Proceeding Series, 89. Atlanta, Georgia. 